\title{
The Netherlands: The Paradox of Government-Nonprofit Partnerships
}

\author{
Taco Brandsen and Ulla Pape
}

\begin{abstract}
This article illustrates the development of government-nonprofit collaboration in The Netherlands. It first gives an overview of scope and structure of the non-profit sector and voluntary work and then explains the crucial steps in the evolution of partnership arrangement between the public sector and nonprofit institutions. The article describes the past significance of so-called pillarization on the development of the nonprofit sector and its collaboration with the state. In accommodating a broad diversity of nonprofit organizations with different religious and societal background, The Netherlands created an elaborate mechanism for government-nonprofit collaboration in which nonprofit organizations fulfil functions in service delivery and policy formation. However, the sector is now fundamentally fragmented and now has little shared identity left. Paradoxically, its past success also makes it less likely that the Dutch nonprofit sector will be regarded as a solution to current social problems.
\end{abstract}

\section{Keywords}

Partnership, third sector, civil society, corporatism, human services 


\section{Introduction ${ }^{1}$}

Partnerships between the state and the nonprofit sector are widely perceived to be a new phenomenon. In fact, however, they have a rich history (Bode and Brandsen, 2014). Salamon (1995) has shown, for example, that even in the United States, a country better known for the philanthropic origins of its nonprofit sector, the earliest nonprofits relied heavily on governmental support. Especially where state - nonprofit sector partnerships were institutionalised early, a different narrative is needed since collaborative service provision as such has been a traditional feature there (Bode, 2011). This is especially true of a country like The Netherlands.

The evolution of government-nonprofit relationships in The Netherlands cannot be separated from the evolution of the entire political system (Aquina 1992). By virtue of close collaboration with government, the Dutch nonprofit sector has attained a huge role in the delivery of human services. Reflecting this, its employment ranked higher as a share of the country's total employment than in any of the other countries examined in the Johns Hopkins Comparative Nonprofit Sector Project (Salamon et. al. 2004). Whereas in many other countries the involvement of the third sector is seen as a new type of governance (Osborne 2006), in The Netherlands it represents the status quo. This testifies to the major significance of the sector in resolving historical conflicts arising from the country's social diversity. But this has come at a price. What the statistics do not show is that the Dutch nonprofit sector is now fundamentally fragmented and has little shared identity left at this point. As far as human services are concerned, both advocacy and service delivery are generally confined within vertical policy pillars. There is at this point hardly any nonprofit 
sector identity that unites organizations across policy fields. Whether that is a problem is a point of discussion.

This chapter will give a brief overview of the Dutch non-profit sector and how its collaboration with the state had evolved over time. It will end with some suggestions of what could be learned from the Dutch experience.

\section{The Current Situation: The Scope and Structure of Government Support of Nonprofit Human Service Delivery in The Netherlands}

In the Johns Hopkins study, in the mid-1990s the Dutch nonprofit sector emerged as among the largest in the world. In terms of non-agricultural employment, it was indeed the largest with $12.9 \%$. The major share of this employment was in social welfare services - particularly health care, education and research, social care and social housing (Burger and Veldheer 2001).

To a large extent this is related to the structure of welfare state spending, which for historical reasons has been to a large extent channelled through the private non-profit sector, as it was in countries like Austria, Belgium and Germany. In some respects, the numbers even underestimate the sector's role in the Dutch case. Data based upon employment fail to include the Dutch social housing sector, which has relatively little employment, but large capital stocks and transfers. In the Netherlands, social housing has for a long time been virtually monopolised by nonprofits and controls about a third of the total housing stock, amounting to over 100 billion Euro in assets (Helderman 2007). Despite recent attempts to shrink it, which are likely to continue 
over the coming years, this still well exceeds the proportion of social housing in other European countries.

However, this is not to suggest that the sector's size can be explained only with reference to its role in the welfare state. As in Scandinavian countries, a large welfare state and a vibrant voluntary sector go hand-in-hand. Voluntary work again made it proportionately the largest (Schuyt et. al. 2013). Of revenues in the fields of health care, education and research, social care and social housing, 66\% came from public (state) sources, $33 \%$ fees and other commercial income, and 1\% from private giving; while overall, it is $59 \%$ public, $38 \%$ fees, $3 \%$ charity. Such statistics attest to the historical significance of the nonprofit sector. In terms of employment, it makes a major contribution to the economy.

\section{How Did We Get Here?}

To understand the sector's economic prominence in the Netherlands, it is important to take account of its key role in reconciling broader political conflicts. The Dutch nonprofit sector was in fact traditionally called 'maatschappelijk middenveld' ('societal midfield'), a term coined by the Dutch sociologist Van Doorn in the 1970s (Van Doorn 1978). This term stresses the intermediary position of organisations and groups between the state and the citizens (and not between state and market).

\section{The accommodation of diversity}

Dutch society was from the outset characterised by strong religious and political diversity. When the Netherlands split off from the Spanish empire in the 16th century 
and became the Republic of the Seven United Provinces, it faced strong internal divisions, especially along religious lines. After early bouts of persecution, the tradition became one of restrained religious tolerance, allowing minorities to practise their religion privately. From an early stage on, nonprofits such as charitable organisations had a significant role in society (Van Voss and Van Leeuwen 2012). By the early 20th century, this had developed to the point where different social groups were organised in so-called 'pillars' (Lijphart 1968): integrated configurations of organisations with a common identity (Catholic, Protestant, and Socialist). For example, a Catholic family would read a Catholic newspaper, send their children to a Catholic school, join the Catholic football club, and so forth. Organisations within the pillars were usually connected through personal networks rather than formal ties. The strong social segmentation could easily have led to conflicts, but this did not happen because the political elites of each pillar were pragmatic and pursued consensus-based decision-making. They encouraged their 'flock' to be loyal to their own pillar (in the literature, this process is usually labelled as 'vertical integration') while simultaneously engaging in consensus-based decision-making at the top, referred to as 'horizontal integration' (Visser and Hemerijck 1997).

This was first brought to a head in one especially significant vertical field: education. In the so-called 'battle of schools', the highly contentious issue was whether private (esp. religious) schools should receive the same funding as public schools. In 1917, the liberals and the religious parties came to a compromise ('pacification'): in exchange for universal suffrage, religious schools received the same funding and rights as their public counterparts. This compromise on education was considered so important that it was even included in the constitution. The principle developed for 
schools then spread to other vertical fields of service delivery. There was to be no differential treatment between public organisations and nonprofit sector organisations, often related to denominations. This style of policymaking was aimed at depoliticisation - turning ideological clashes into 'technical' issues. The Catholic notion of subsidiarity and the Calvinist notion of circles of sovereignty sat happily side by side within this system of distribution. The nonprofit sector therefore not only provided a means for political emancipation, but also helped to take difficult issues of distribution out of the political arena.

When the welfare state expanded after the Second World War, pillarisation became the organisational principle through which its growth was channelled. In most policy fields, the nonprofit sector represented an acceptable compromise between state growth (opposed by liberals of the Right) and market solutions (opposed by the social democrats of the Left). The effects of this policy on the nonprofit sector were twofold. Organisations involved in service delivery could grow at an exponential rate, assured of increasing public funding. However, this meant that the money brought regulation that not only diminished their autonomy, but also gradually blurred the distinction between public and nonprofit - private - agencies. For instance, it was difficult to maintain bonds with specific client groups when the regulatory framework promoted equal access and uniform standards. This occurred at a time when the system of pillarisation was already starting to erode.

Pillarisation involved the incorporation of social groups into an organisational network based on religious or ideological affiliation (Lijphart 1968). In the 1950s, particularly among Catholics and Protestants, adherence to organisational networks 
on a religious basis was very strong. For example, in $196481 \%$ of the members of the Catholic trade union and $76 \%$ of the members of the Catholic broadcasting company voted for the Catholic political party; the numbers were $68 \%$ and $72 \%$ for Protestants, respectively.

\section{Erosion of the pillars}

By the 1960s, however, the pillars went into decline, especially the Catholic one. The role of religion in public life declined; the number of non-affiliated organisations grew; the informal links within the pillars weakened; links between the pillars strengthened; and the Catholic church discontinued its previous policy of demanding strict allegiance of Catholics to Catholic organisations (Aquina 1992). This erosion of the pillars has also been visible in the use of language. Notions like maatschappelijk middenveld, subsidiarity and circles of sovereignty are less frequently used and generally associated with the past, not with current issues. Simultaneously, the organisations have become integrated with bureaucratically defined policy fields. Many still bear a particular denominational label, but it has only minor effects on what they do, who they work with and who they work for. They identify more with other organisations (public, commercial or private non-profit) delivering the same types of services than with nonprofits in other fields. The traditional, ideologically and religiously differentiated, pillars were therefore essentially superseded by vertical field-specific policy pillars. Organisational growth, bureaucratisation and mergers (often between organisations with different denominational backgrounds) added to the loss of historical character. For instance, many primary schools have now joined larger non-profit holding companies, which often include different denominations. 
However, other types of schools have emerged in the meantime, based not on traditional ideologies, but on alternative pedagogical concepts.

During the 1980s and 1990s, the government changed its governance of servicedelivering organisations, inspired by the New Public Management ideology of the period (Pollitt and Bouckaert, 2004). Although these were not measures aimed at the non-profit sector specifically, they impacted on the nonprofit sector significantly, since the sector was so heavily involved in state-funded human service delivery. There was continuity in the sense that private nonprofit delivery of public services remained common and generally accepted. Many of these organisations received a larger share of managerial autonomy. However, they also became subject to stronger performance measurement and output control. Although everywhere there was much emphasis in policy discourse on strengthening market mechanisms, the actual measures and effects have differed strongly. In some policy fields, traditional nonprofits were seriously weakened by new commercial entrants (especially in domiciliary care), but in most fields the direct effects of competition were limited.

The retreat of the state during this period can in no way be interpreted as 'a return to the roots', or a reversal of a historical trend. The nonprofits delivering human service were by then very different from the small, semi-philanthropic organisations that they had been a century before. Also, it very much depends on what part of the nonprofit sector one is looking at. The partial incorporation of the nonprofit sector into the welfare state had deepened the division between organisations that still largely relied on volunteers and those that provided professional services. The latter had grown increasingly less dependent on voluntarism and more dependent on state and/or 
commercial funding. In many respects, they were similar to privatised public agencies, to public agencies that adopted certain non-profit characteristics and to commercial businesses involved in public service delivery (Van de Donk 2001; Dekker 2004). It is no coincidence that scientific work on hybrid organisations, in the sense of cross-cutting civil society, market and state, was at its early stages in the 1980s and 1990s dominated by scholars from Germany and The Netherlands, countries where the non-profit sector was caught up in the shift in governance paradigms (see, for example, Evers 2005; Bode 2011).

These developments have led to a significant difference between the service delivery part of the sector, on the one hand, and the voluntary sector, on the other. We will discuss the latter in the next section.

\section{The voluntary sector}

As noted earlier, volunteering in the Netherlands is still at a comparatively high level, even if it faces similar challenges as in other countries (for more elaborate information, see Dekker, 1999; 2001). According to the Giving in the Netherlands panel survey, $38 \%$ of the Dutch population was engaged as a volunteer in unpaid work for an organization at least once in the previous year (Schuyt et al. 2013). In addition, many Dutch citizens are involved in informal groups and initiatives (Berg et al. 2011). In the social sector, informal care, organized for example through neighbourhood initiatives, plays an increasingly important role. Membership levels of voluntary organisations have proved fairly stable, even if there have been shifts from traditional membership organisations (political parties, trade unions, churches) 
towards sports and recreation (Dekker et al. 2007; Dekker and De Hart 2009). The recent economic crisis does not seem to have affected this significantly (Posthumus et. al. 2014). To the contrary, in terms of membership development and trends in private donations, the nonprofit sector shows a stable development (Van den Berg and De Hart 2008; Posthumus et al. 2014).

Yet institutionally one is faced with a paradox. On the one hand, there is an active and well-funded infrastructure to support voluntary organisations in The Netherlands. Dutch 'organised volunteering' has a visible presence on the international scene. In the Netherlands, voluntary organisations are represented by the Association of Dutch Voluntary Effort Organizations (NOV) which unites approximately 350 member organisations. NOV leads an active policy to promote volunteering among Dutch citizens and advocates for a public recognition of voluntary effort. Despite a high organizational degree of voluntary organizations and the visibility of the umbrella network, volunteering is not high on the political agenda and, insofar as there have been official policies supporting it, they have been largely of a symbolic nature. Recent governments have been vocal in their support of citizen participation, but mostly with a focus on informal care or as a vehicle for social innovation. The traditional voluntary sector has been largely ignored in this recent policy discourse. How can volunteering have such a low priority in current policymaking and yet be so well-organised? The reason, as I will argue, is a combination of success, decentralisation and organisational funding that explains this apparent contradiction.

There is a 'framework' for supporting volunteers that channels its subsidies through local and regional authorities, and there have been measures to encourage 
volunteering among young people. However such subsidies are mostly temporary and not formulated as components of a programme of investment. For instance, in 2006, volunteering was made more attractive in fiscal terms, raising the level of cost reimbursement for volunteers exempted from taxes, mainly as an administrative costsaving measure for voluntary organisations. It would go too far to discount such measures as symbolic only, but most have been low-profile and none have attracted significant funding. The focus in employment policy is very much on paid employment, and there are no direct links between volunteering policy and general employment policy, which reside with different Ministries.

As noted above, if volunteering is linked to more high-profile policy issues, it is mainly in the context of care and social support, e.g. care for diseased or elderly relatives as an individual, unorganised activity. Significant policy developments took place in the area of social services (Wet Maatschappelijke Ondersteuning), which was introduced in 2007 and recently reformed. Most of the funding and responsibility for social services was delegated to local authorities, while leaving citizens more freedom to organise their own support. One of the explicit aims of these policy initiatives has been to encourage participation and self-organised support, as state-funded services are being cut down (Mensink et al. 2013). For instance, as homes for the elderly are being closed down, the elderly are encouraged to continue living at home, with a combination of professional and informal support organised by family, friends and neighbours. The traditional voluntary sector has made attempts to carve out a role for itself in organising support (e.g. through matching schemes), but this is a bottom-up development that has been largely ignored in policy circles. The current process of decentralisation puts a stronger emphasis on voluntary organizations and individual 
voluntary activity at the local level. This process is believed to open up opportunities for community-based organisations and initiatives. However, decentralisation has also faced criticism, as organizations and individuals see themselves confronted with increased - and in the eyes of some unrealistic - expectations regarding the role of volunteers in the provision of human services.

Generally, policies geared towards volunteering as such have been rather lacklustre. While various voluntary organisations are subsidised, there is little effort to draw all this into a coherent policy framework. The government did establish a committee on volunteering policy in 2001 that developed instruments for encouraging and facilitating volunteering at the local level by local or regional authorities. However, apart from the measures related to the recent decentralisations, there have been no significant policy initiatives to encourage volunteering. Administratively, volunteering is lumped under the general heading of 'welfare', which comprises a wide variety of organisations, both professional and voluntary. The influence of voluntary organisations is dwarfed by that of the larger, professional organisations active in this field, such as research institutes and think tanks.

It is in the combination of success, decentralisation and organisational funding that the paradox of Dutch volunteering may be understood. First, one could argue that there is little need for policy initiatives on volunteering when overall levels of participation are still so high. There is no wide sense of urgency. Second, there is a strong set of organisations that can effectively encourage volunteering without a need for official government policy. Much of this takes place at the local level, on the grounds that this is where the state can target its support most effectively - an 
institutional framework consistent with the principles of both the Social-Democratic, Liberal and Christian-Democratic parties, who jointly shaped the post-war Dutch welfare state. If there has been a consistent government policy on volunteering, it has perhaps been to delegate the freedom and funding to take initiatives to a set of national and local specialist organisations. From the outside, the active role of Dutch organisations in the field of voluntarism may appear to be an indicator of strong political support, but this interpretation may rest upon a fundamentally confused notion of centralised and decentralised political systems. The organised volunteering infrastructure can thrive without and beyond politics.

\section{The Tools of Action in Government-Nonprofit Relations}

In looking at the tools of action in government-nonprofit collaboration in The Netherlands, one must make a distinction between the general framework that nonprofits work in and the more specific tools that are used within policy fields.

A typical feature of the Dutch nonprofit sector is that the vast majority of organisations are either associations or foundations. The cooperative movement has been of negligible importance (except in the business sector, where it has some famous representatives). In the human services, nearly all organisations have now become foundations, even though the association remains dominant in the voluntary sector. The legal regime over the activities of foundations is fairly light. Apart from field-specific requirements attached to state subsidies and fiscal privileges, there are no major constraints other than the non-distribution constraint. There are no specific 
requirements concerning the composition, appointment, suspension or dismissal of board members (nor is it even necessary to have Dutch board members). It is not mandatory to publish annual accounts. There can be a one-tier governance structure, without a supervisory board, though nearly all organisations in the human services would have one. The emergence of these favourable conditions is historically related to the importance of the nonprofit sector in creating a sustainable political system. It has also, incidentally, made The Netherlands a particularly attractive home base for shady organisations active in crime, terrorism or tax evasion. This general framework is fairly robust, while at the same time leaving a fair amount of flexibility.

Other than this legal organisational framework, there is no generic framework for nonprofit organisations. Within the Dutch government there is no such thing as a 'nonprofit sector policy', nor is there any specific policy unit in any of the Ministries with a focus on the nonprofit sector. What comes closest is the Department of Social Policy in the Ministry of Health, Welfare and Sports, which has volunteering listed as one of the elements in its policy field. However, this is only a minor unit within a Ministry that is largely and increasingly concerned with health care policy. For the human services, there is no overarching policy.

For organisations in the human services, the more direct interventions from government would be through funding and the conditions attached to it, or to general regulation pertaining to specific policy fields. These vary among fields and it would be impossible to give a satisfactory description of them, especially as the complexity of some fields like health care warrants a book of its own. The key point to make here 
is that the nature of collaboration with nonprofits is conditioned by the nature of the policies and not by their sectoral identity.

In primary schools, for instance, public schools (i.e. those schools directly controlled by local governments) work within exactly the same funding conditions as schools based on a religious identity (usually Catholic, Protestant or Islamic) or on an alternative pedagogical philosophy (e.g. Montessori, anthroposophical). Religious schools have the freedom to select pupils and teachers based on their beliefs, but this is legally limited. For instance, some years ago their right to refuse to hire homosexual teachers was removed. They have the right to give some religious classes. However, the curriculum, teaching qualifications and learning objectives are centrally determined, as are a host of other regulations, so in the end the differences between schools from different backgrounds are fairly small. However, it would be mistaken to conclude that the development has been a straightforward one towards bureaucratisation of nonprofits. Even public schools have a fair measure of autonomy and some measure of participation by parents, since the design of their regulatory framework was in turn influenced by the nonprofit tradition. The end result is a blend of public and nonprofit characteristics, within one overarching framework.

\section{The Nonprofit Role in Policy Formulation}

As it is so strongly involved in the delivery of human services, non-profit organisations have regular interactions with the government, through formal consultation procedures in which all stakeholders of policies are involved. In addition 
to these formal mechanisms, there are various informal networks at play. Government members or members of parliament may have a history in the nonprofit sector or may be on their supervisory boards. Given the strong role of the sector in key services, combined with the fact that most active politicians nowadays have a labour market background in the (semi-)public sector, this is not at all surprising. The Netherlands have a tradition of consensual decision-making, which favours advocacy by nonprofits. They may be very influential, though is of course hard to assess. What complicates such measurement is that advocacy also takes place at the local level, which is becoming increasingly important after successive decentralisations (Lelieveldt 1999). Most nonprofit organisations use informal networks and personal contacts for their advocacy. Based on the cultural value of consensus seeking, advocacy by Dutch nonprofit organization often takes the form of informal consultations and information sharing with political decision makers, rather than public advocacy campaigns or naming-and-shaming approaches. Due to the informality of policy networks, the advocacy impact of nonprofit organizations is difficult to assess. Organizations, however, report that political decision makers in general show themselves accessible to the nonprofit organizations that they regard to be knowledgeable in their respective policy fields (Brandsen and Pape 2015).

Like service delivery itself, advocacy occurs largely within the separate institutional pillars of policy fields. The cross-cutting function of the pillars was never as important as it was in a country like Germany (comp. Zimmer 1999). In the context of a federal political system, the German Free Welfare Associations have traditionally had a significant role as facilitators and conduits of public policy. In a decentralised, but unitary and relatively small state such as the Netherlands, the need for such 
facilitating institutions was never as great as it was for its large neighbour. Within the pillarised framework of former times, nonprofit organisations had ties with politics through informal personal networks cutting across industries. Although such networks still partially exist, their co-ordination and extent have diminished with depillarisation. As discussed above, secularisation and individualisation have eroded the old pillars, of which little more remains than institutional remnants. As a unified concept, the nonprofit sector is rarely discussed in politics. Although it occasionally is used in the margins of broader discussions, these are generally about the status and governance of certain types of organisations or activities (e.g. about funding for volunteering in elderly care) rather than discussions about the nonprofit sector itself. There are certain policy issues that could easily be linked to this generic identity, but are not. The Christian-Democratic Party (CDA) - which has historically been the most fervent supporter of the maatschappelijk middenveld - has become far less dominant in national politics and has in recent years focused its energy primarily on individual responsibility and citizenship, even though it did support some initiatives in volunteering.

This means that the significance of institutional channels within the policy fields has grown, while the social structure supporting cross-cutting networks has crumbled. One could say that the 'pillars' of state organisation have replaced (or at least been grafted onto) the religious and political pillars into which the Dutch nonprofit sector was traditionally divided. The organisations involved are now visibly influenced by intra-field policy rather than visible politics. Awareness of an overarching nonprofit sector understood in the traditional way has consequently faded. Paradoxically, its past success also makes it less likely that the Dutch nonprofit sector will be regarded 
as a solution to current social problems. Because it has been closely intertwined with social policy, the problems of social policy are its own. In many countries, its involvement is regarded as a potential solution to problems of innovation, accountability and participation. But this is hardly a credible policy position in a country where the nonprofit sector has been involved in service provision for years. Rather, as part of the broader group of service providers, it is often regarded as part of the problem (for example, in being unresponsive to clients).

\section{Key Issues in Government-Nonprofit Cooperation in the Provision of Human Services}

An issue arising for nonprofits in a context of such close collaboration with the state is the effect of accountability measures. It is of course an old point that such organisations may become more bureaucratic when dealing with governments (Smith and Lipsky 1993). The Dutch case is no exception. A second effect is loss of autonomy, though to what extent is hard to say. Accountability measures may have quietly eroded formal autonomy, making organisations more dependent than they may seem at first sight. It has even been noted that, by co-opting the nonprofit sector into its policy agenda, the state may be effectively colonising key spheres of social life and create a 'manufactured civil society', trying to reshape those they collaborate with (Hodgson 2004; Brandsen et al. 2017). This is a far cry from the friendly and optimistic partnership discourse.

More specifically, many of the organisations have in recent years felt burdened by an increasing amount of paperwork (Brandsen et al. 2011). Recent research has shown 
that governmental funding schemes force them to spend more time on administrative procedures than on their service for clients. The introduction of new forms of accountability such as stakeholders forums, online reporting, benchmarks and peer review has added to this. Staff members are required to comply not only with more, but also with increasingly contradictory criteria. These are symptoms of what Koppell has aptly termed "multiple accountabilities disorder" (Koppell 2005). The fatigue of staff members was mirrored by stakeholders, especially individual clients, who showed increasing disinterest in being consulted and involved. Especially in the social sector, nonprofit organization report about the administrative burden of accountability mechanisms (Brandsen and Pape 2015). Increasing dependence on governmental funding schemes makes organizations feel that they lose the ability to work independently and preserve a critical distance to the drawback of public reforms.

Interestingly, the emphasis on accountability does not appear to have done the organisations much good. A number of them have in fact been publicly accused of mission drift and abuse of their position. The social housing providers recently faced a parliamentary enquiry that reached damning conclusions, accusing them of squandering money and having lost touch with their original purpose (Parlementaire Enquete Woningcorporaties 2014). This followed a spate of scandals that, though not representative of the entire sector, left them with a terrible reputation in the eyes of the public. Similar scandals have on a lesser scale occurred in elderly care, health care and higher education. Many of the organisations in these fields have to a large extent become hybrids (Brandsen et al. 2005). An attempt to rebrand themselves as 'social entrepreneurs' a decade ago failed quite badly (Brandsen and Van de Donk 2009). An alternative strategy has been to increase the participatory element in their governance 
structures is the direction that they may be going in, although as noted above this has not necessarily invited waves of enthusiasm. In other sectors, too, nonprofit organizations face harder questions about their legitimacy and accountability towards the public. Charitable mission alone, without the ability to guarantee effective internal control, is no longer seen as sufficient for operating successfully.

\section{Lessons for Russia}

This theme issue focuses on the experiences of Russia and the lessons it could potentially learn from other countries. Can Russia learn from The Netherlands?

In the 17th century, Tsar Peter the Great visited the Dutch Republic, then the leading economic power in Europe, to learn lessons from the country's craftsmen and scientists. He studied advances in cartography, navigation, medicine and trade. $\mathrm{He}$ even spent some time working in a shipyard, watching the process of naval construction from the inside. Much of his newly acquired information was put to immediate use and inspired his attempts to modernise the Russian economy and state. To this day, the Dutch influence is visible in the layout of St Petersburg. It is a tempting parallel, but a misleading one.

For a start, the Kingdom of The Netherlands today is not the innovation powerhouse that the Dutch Republic was in the $17^{\text {th }}$ century. More importantly, one should be careful in transplanting systems or policies from one country to the other. Exchanging good practices is a good idea, but adopting technologies is quite different from 
copying a social system. Constructions of a social and political nature are far more contextually bound than their technological counterparts (Evers and Brandsen 2015). An iPad will continue to function in more or less the same way whether it is used in Moscow, Rotterdam or Aswan. The same cannot be said of systems or arrangements that work with people and rely on specific regulations and cultures to be effective. Also, the same arrangements may carry very different cultural meanings in different national contexts (Andrews and De Vries 2007; Brandsen and Kim 2010). This is of course relevant to the issue of learning lessons. A social system is the result of a specific combination of regulatory, economic, political and cultural conditions. Transplanting it elsewhere requires a thorough adaptation. If this process is badly handled, by people with only superficial knowledge of the places where reforms are introduced, the consequences can be disastrous. The market liberalisations of the 1980s and 1990s provide a case in point. Dutch institutions operate within a tradition of consensus building and egalitarianism within the administration and society at large. Attempts to introduce them in our former colonies have sometimes yielded rather surprising results.

Having said that, what are the potential benefits of the Dutch 'model'? The sector has historically played a key role in accommodating diversity in society, diffusing tensions that might otherwise have led to severe political disruption. Although the nature of this role has changed over time, it is still an important element in how key elements in Dutch society operate. The relationship between governments and nonprofits in The Netherlands has on the whole been a constructive and harmonious one. Although with the involvement of so many organisations and citizens there have been 
inevitable hiccups, the relationship has predominantly been consensual rather than oppositional.

Certain regulatory and cultural conditions would need to be in place to replicate these effects. First, it would require a level playing field between non-profit and public providers, with the possibility to channel budgets for public services through nonprofits that would be in charge of delivery. Equality of standards is a means of diffusing tension where human services have to be delivered to groups with diverse backgrounds and diverse ideas of what counts as a good service. Giving citizens more ownership of their services through private delivery can go hand in hand with a robust regulatory framework. The pillarised arrangement of the 20th century Dutch politics effectively removed political controversy from human service delivery and from society more generally.

Second, it would require a shift of emphasis from input- to output-based governance. The state should be able to monitor the quality of its service by means of clear standards. For instance, pupils of private nonprofit schools can be tested through state exams. In other policy fields, too, external quality standards are a means of improving service delivery. How those standards are ultimately achieved can to a large extent be left to the nonprofit organisations to determine. Finding the exact balance between input- and output-based governance is likely to be an ongoing process.

Finally, it would require the state to respect the autonomy of nonprofit organisations and allow them the freedom to express themselves critically. In a well-functioning partnership, nonprofit organizations can function as bridges between service provision 
and communities. They can combine their functions of service delivery and advocacy, playing a role both in providing services and in the process of continuously improving them in co-governing policy development.

It hardly needs saying that the manner of the implementation is a key factor here. No matter how the formal system is devised, it requires a certain cultural relationship and mutual respect to make it work. It would be naïve to suppose that these conditions exist in the present Russian context and that our suggestions are anything more than a thought experiment.

Peter the Great was astounded by the irreverence of Dutch servants - no doubt he never aimed to copy that particular element of his host country. Would the current Russian leadership be happy for citizens to adopt Dutch cultural attitudes?

\section{Notes}

1. The analysis is based on work in the Third Sector European Policy (TSEP, 20052008) and Third Sector Impact (TSI, 2014-2017) projects. Part of it was previously published in Brandsen and Van de Donk (2009). Since one of the authors is editor of this journal at the time of publication, we would like to note that the decisions to plan and publish this text was taken prior to this period. 


\section{References}

Andrews, C. W. and M.S. De Vries (2007). High expectations, varying outcomes: decentralization and participation in Brazil, Japan, Russia and Sweden. International Review of Administrative Sciences, 73, 424-451.

Aquina, H.J. (1992). A partnership between government and voluntary organizations: changing relationships in Dutch society. In B. Gidron, R.M. Kramer and L.M. Salamon (eds.), Government and the Third Sector: Emerging Relationships in Welfare States, San Francisco: Jossey-Bass Publishers, pp. 57-74.

Berg, E. van den, and J. de Hart (2008). Maatschappelijke organisaties in beeld. Grote ledenorganisaties over actuele ontwikkelingen op het maatschappelijk middenveld, SCP, The Hague.

Berg, E. van den, P. van Houwelingen, and J. de Hart (ed.) (2011). Informele groepen. Verkenningen van eigentijdse bronnen van sociale cohesie, SCP, The Hague.

Bode, I. and Brandsen, T. (2014). State - third sector partnerships: a short overview of key issues in the debate: introduction to the special issue on state - third sector partnerships. Public Management Review, 16, 1055-66. 
Brandsen, T., W. van de Donk and K. Putters (2005). Griffins or chameleons? Hybridity as a permanent and inevitable characteristic of the third sector, International Journal of Public Administration, 28, 749-65.

Brandsen, T. and Van de Donk, W. (2009). The third sector and the policy process in the Netherlands: a study in invisible ink. In J. Kendall (ed.), Handbook on Third Sector Policy in Europe: Multi Level Processes and Organised Civil Society, Edward Elgar, Cheltenham, 140-58.

Brandsen, T. and Kim, S. (2010). Contextualising the meaning of public management reforms: a comparison of the Netherlands and South Korea. International Review of Administrative Sciences, 76, 367-86.

Brandsen, T., Oude Vrielink, M., Schillemans, T. and Van Hout, E. (2011). Nonprofit organisations, democratisation and new forms of accountability: a preliminary evaluation. In A. Ball and S.P. Osborne (eds.), Social Accounting and Public Management, Routledge, London.

Brandsen, T., Pape, U. (2015). Barriers and opportunities of third sector development in The Netherlands, National Report - The Netherlands, TSI working paper series, forthcoming.

Brandsen, T., Trommel, W. and Verschuere, B. (2017). The state and the reconstruction of civil society. International Review of Administrative Sciences, 83, forthcoming. 
Burger, A., and Veldheer, V. (2001). The growth of the nonprofit sector in the Netherlands. Nonprofit and Voluntary Sector Quarterly, 30(2), 221-246.

Dekker, P. (ed.) (1999). Vrijwilligerswerk Vergeleken, SCP, The Hague.

Dekker, P. (2001). Nederland gemeten en vergeleken: conclusies en perspectieven. In A. Burger and P. Dekker (eds.), Noch Markt noch Staat: de Nederlandse NonProfitsector in Vergelijkend Perspectief, SCP, The Hague.

Dekker, P. (2004). The Netherlands: from private initiatives to non-profit hybrids and back? In A. Evers and J.-L. Laville (eds.). The third sector in Europe, Edward Elgar, Cheltenham.

Dekker, P., J. de Hart and L. Faulk (2007). Toekomstverkenning vrijwillige inzet 2015, SCP, The Hague.

Dekker, P., and J. de Hart (2009). Vrijwilligerswerk in meervoud, SCP, The Hague.

Donk, W. van de (2001). De Gedragen Gemeenschap, SDU, The Hague.

Doorn, J.A.A. (1978). De verzorgingsmaatschappij in de praktijk. In J.J.A. van Doorn and C.J.M. Schuyt (eds.), De Stagnerende Verzorgingsstaat, Boom, Amsterdam. 
Evers, A. (2005). Mixed welfare systems and hybrid organizations: changes in the governance and provision of social services. International Journal of Public Administration, 28, 737-48.

Evers, A. and T. Brandsen (2015). Social Innovations as messages: democratic experimentation in local welfare systems. In T. Brandsen, S. Cattacin, A. Evers, A. Zimmer (eds.), Social Innovation in the Urban Context, Springer, Heidelberg/New York.

Helderman, J.-K. (2007). Bringing the market back in? Institutional complementarity and hierarchy in Dutch housing and health care. Dissertation. IBMG, Rotterdam.

Hodgson, L. (2004). Manufactured civil society: counting the cost. Critical Social Policy 24, 139-164.

Koppell, J. (2005). Pathologies of accountability: ICANN and the challenge of 'Multiple Accountabilities Disorder'. Public Administration Review 65, 94-108.

Lelieveldt, H.T. (1999). Wegen naar Macht. Politieke Participatie en Toegang van het Maatschappelijk Middenveld op Lokaal Niveau,, Thela Thesis Publishers, Amsterdam.

Lijphart, A. (1968). The Politics of Accommodation: Pluralism and Democracy in the Netherlands, University of California Press, Berkeley. 
Mensink, W., A. Boele, and P. van Houwelingen (2013). Vrijwillige inzet en ondersteuningsinitiatieven. Een verkenning van Wmo-beleid en -praktijk in vijf gemeenten, SCP, The Hague.

Osborne, S.P. (2006). The New Public Governance? Public Management Review, 8, $377-387$.

Parlementaire Enquete Woningcorporaties (2014). Ver van Huis: Hoofdrapport Parlementaire enquêtecommissie Woningcorporaties, Parliamentary Year 2014-2015, 33606, nr. 4.

Pollitt, C. and Bouckaert, G. (2004). Public Management Reform: A Comparative Analysis, $2^{\text {nd }}$ edition, Oxford University Press, Oxford.

Postumus, H., den Ridder, J., and J. de Hart. (2014). Verenigd in Verandering. Grote maatschappelijke organisaties en ontwikkelingen in de Nederlandse civil society, SCP, The Hague.

Salamon, L. M. (1995), Partners in Public Service: Government-nonprofit Relations in the Modern Welfare State, Johns Hopkins University Press. Baltimore Md.

Salamon, L., H.K. Anheier, R. List, S. Toepler, S.W. Sokolowski, and Associates (2004) Global Civil Society: Dimensions of the Nonprofit Sector, Volumes One and Two. Johns Hopkins University, Baltimore Md. 
Schuyt, Th.N.M., Gouwenberg, B.M. and R.H.F.P. Bekkers (eds., 2013). Giving in the Netherlands: Donations, Bequests, Sponsorship and Volunteering, Reed Business, Amsterdam, available at http://www.giving.nl/ (accessed 7 July 2015).

Smith, S.R. and M. Lipsky (1993). Nonprofits for Hire: The Welfare State in the Age of Contracting, Harvard University Press, Cambridge.

Van Voss, L.H. and M.H.D. van Leeuwen (2012). Charity in the Dutch Republic: an introduction. Continuity and Change. 27, 175-197.

Visser, J. and A. Hemerijck (1997). A Dutch miracle: Job Growth, Welfare Reform and Corporatism in the Netherlands, Amsterdam University Press, Amsterdam.

Zimmer, A. (1999). Corporatism revisited: the legacy of history and the German nonprofit-sector. Voluntas 10, 37-49. 